\title{
M-learning: A Nexus for Adult Learners' Motivation and Readiness to Learn in Federal Universities at Southwest, Nigeria
}

\author{
Bamidele Victor Aremu ${ }^{1 *}$, Olufemi Victor Adeoluwa ${ }^{2}$
}

${ }^{1}$ Federal University Oye Ekiti, NIGERIA

${ }^{2}$ Ekiti State University, NIGERIA

*Corresponding Author: helebami@gmail.com

Citation: Aremu, B. V., \& Adeoluwa, O. V. (2022). M-learning: A Nexus for Adult Learners' Motivation and Readiness to Learn in Federal Universities at Southwest, Nigeria. Journal of Digital Educational Technology, 2(1), ep2201. https://doi.org/10.21601/jdet/11361

ARTICLE INFO

Received: 27 Jul. 2021

Accepted: 12 Oct. 2021

\begin{abstract}
The aim of this study was to examine the perspective of adult learners on the relationship that exist between motivation to learn, readiness to learn and the use of m-learning for teaching and learning activities. In order to accomplish this, descriptive research survey design was adopted by this study. The population of the study comprised of adult students at the distance learning programmes of Federal Universities in Southwest, Nigeria. The sample for the study comprised of one hundred and twenty adult learners that were selected using multistage sampling techniques. A questionnaire was designed for data collection and validated through face and content validity while the reliability was done through Cronbach Alpha with coefficient 0.89 . Collated data were analyzed through simple percentage and Pearson product moment correlation. The findings revealed that adult learners use mobile devices and there are significant relationships between motivation to learn, readiness to learn and the use of m-learning. It was recommended that m-learning should be formally introduced into adult education programme in Nigeria.
\end{abstract}

Keywords: m-learning, adult learners, motivation to learn, readiness to learn, teaching-learning activities

\section{INTRODUCTION}

Education is a lifelong experience and the right of all the citizens of a country, either youth or adult. The education programmes for working adults are tagged adult education and it serves many purposes. Adult education is a channel through which adults in a society can develop cognitive, affective, and psychomotor skills for the purpose of achieving societal goals. Adeji and Tunde (2020) were of the opinion that adult education serves as a path to solving the social, economical, cultural, political and environmental challenges of a society. Literacy, continuing education, remedial education, civic education, and on-the-job training are the rationale behind the establishment of adult education in Nigeria (FGN, 2004). Adult education could be linked with distance learning education and sandwich programmes that are handled by many institutions through satellite campuses, correspondence studies, and summer semesters. The advent of modern technology such as electronic learning (e-learning), mobile learning (m-learning), massive open online courses (MOOCs) and online collaborative learning may also be incorporated into the teaching and learning experience of adult learners.

Learning through mobile devices is commonly known as mlearning; it involves the use of laptop computers, I-pads, mobile phones, tablets and personal digital assistants (PDAs) that are connected to the internet for unlimited learning experiences (Rahamat et al., 2017). M-learning combines the use of mobile devices and the internet for learning. It develops from e-learning with the purpose of delimiting the challenges of space and time. M-learning offers learning content which facilitate the construction of knowledge outside normal classroom learning period. The module operandi of m-learning focuses on the learning dynamism of the learner and the suitable utilization of the handheld durable learning devices (Saxena \& Saxena, 2015); thereby, making learners to be part of learning activities without being bothered by mobility and the learning environment (Kukulska-Hulme \& Sharples, 2016; Kukulska-Hulme et al., 2017).There are four learning processes that supports m-learning, these processes are individualized learning which allows learners to learn at their conveniences; situated learning which makes learners learn through mlearning tools within an authentic learning environment; collaborative learning which makes learners to easily interact and communicate with one another through m-learning tools; and informal learning which makes learners to learn at anytime and anywhere (Cheon et al., 2012). These processes could motivate students to learn.

Motivation is an essential factor in learning. Learners can be motivated to learn through the use of mobile devices. 
Learners' motivation to learn is a function of the utilization of learning devices (Barreh \& Abas, 2015; Harandi, 2015). Levy et al. (2013) revealed that learners who engaged in the use of $\mathrm{m}$ learning tools were highly motivated to learn compared with those who were not. In a study conducted by Parmigiani et al. (2015) through upper secondary school students to examine the position of m-learning tools on the motivation of learners to learn, it was found out that the participants considered mlearning as a tool that enhanced motivation to learn. Another study revealed that the m-learning is a channel that motivates learners to learn and participate in learning activities (Sung et al., 2016). Miller and Cuevas (2017) also carried out an experiment on 6th grade pupils. One of the findings of the study revealed that mobile learning devices improve the motivation of learners to learn.

The readiness of learners in Adult Education is considered as one of the significant factors in this study. Previous studies had been carried out on the readiness of learners to use mlearning for educational purposes. The readiness of learners to use m-learning for learning is the preparedness, willingness, eagerness and promptness of students in engaging the $\mathrm{m}$ learning tools such as tablets, phones and laptops to channel learning experience (Padmanathan \& Jogulu, 2018). Sequence to the outcomes of the study conducted by Iqbal and Bhatti (2015) on 244 participants, significant feedback on the readiness to utilize $\mathrm{m}$-learning for learning was inferred. It was shown that approximately $70 \%$ of the participants possessed m-learning device (Smartphone). Following the graphical representation of the study by (Oyelere et al., 2016), there were positive responses on the readiness of both primary and secondary school learners to use m-learning for learning experience. $81 \%$ of the respondents positively indicated readiness to use m-learning for learning adventure. In a study conducted by Wongkhamdi et al. (2017) on 164 participants in Northeastern, Thailand, it was also revealed that $89.5 \%$ of the participants indicated readiness to learn through m-learning. Finally, Rahamat et al. (2017) revealed in an investigation that learners possess the readiness to use m-learning (mobile phone) for learning because $73.2 \%$ of the participants in the study stated readiness for m-learning mode of learning.

Education in Nigeria had constantly undergone devastating interruptions in the teaching and learning activities of her citizens; this has been due to industrial strike actions, riots and recently the outbreak of COVID-19. The results of the interruption in the academic activities usually lead to physical restrictions of teaching and learning activities, inability to gain entrance to learning environment, unavailability of teachers and deprivation of learning opportunities for adult learners and other learners. The consistent interruption of learning in Nigeria either for the youth or adult may be managed through the use of m-learning devices; m-learning devices are readily available and may be used to tackle the inconsistency in the education of Nigerians particularly for adult education. However, the concern of this study is on the motivation and readiness of adult learners to have uninterrupted learning by using m-learning.

\section{PURPOSE OF THE STUDY}

The purpose of this study is to find out the perspective of adult education students on the use of m-learning for their teaching and learning activities. Specifically, this work seeks to;

1. find out the operational skills of the adult learners on mobile devices

2. identify the extent to which the adult learners use mobile devices

3. identify the adaptability of adult learners to finance $m$ learning devices for learning

4. find out the motivation of adult learners to learn by using m-learning

5. examine the readiness of adult learners to to learn via the use m-learning

\section{RESEARCH QUESTIONS}

1. What operational skills of mobile devices do adult learners have?

2. How often do adult learners use mobile devices?

3. How will adult learners cope with the cost of using of m-learning devices for learning?

4. What is adult learners' motivation to learn through mlearning?

5. What is adult learners' readiness to learn through mlearning?

\section{RESEARCH HYPOTHESES}

Ho1: There is no significant relationship between adult learners' motivation to learn and the use m-learning devices.

$\mathrm{Ho}_{2}$ : There is no significant relationship between adult learners' readiness to learn and the use m-learning devices.

\section{METHOD}

This work was carried out through descriptive survey research design. This study was designed to elicit information and describe the perspectives of adult learners on students' motivation and readiness to learn through m-learning. The population for the study includes adult students at the distance learning programmes of Federal Universities in Southwest, Nigeria. The sample for the study was chosen using Multi-stage sampling techniques. Systematic random sampling was used to select three states (Lagos, Oyo and Osun) in Southwest, Nigeria.Purposive sampling was adopted toidentify a Federal University in each of the three statesthat has distance learning programme at the second stage (University of Lagos, Akoka, University of Ibadan, Ibadan and Obafemi Awolowo University, Ile Ife).The thrid stage employed the use of stratified random sampling and simple 
random sampling to select ten students from four strata (Year Two students, Year Three students, Year Four students and Year Five students) in each of universities; this make a total of one hundred and twenty adult learners. The data used for analysis in this study were collected through a questionnaire titled “Adult learners' motivation and readiness to learn questionnaire (ALMRQ). The questionnaire consists of five sections; Section A: Demographic information; Section B: Ownership of mobile devices; Section C: Utilization of $\mathrm{m}$ learning devices; Section D: Motivation to learn via $\mathrm{m}$ learning and Section E: Readiness to learn via m-learning. It consists of 30 items on the motivation and readiness of adult education learners to learn using m-learning. These items were rated using YES and NO option scale. The questionnaire was validated through face and content validity through tests and measurement expert in the field of education. The reliability of the instrument was done through Cronbach Alpha using the response of 10 undergraduates that gave a coefficient of 0.89 . This signifies that the instrument is reliable. The questionnaire was administered to the respondents by the researcher and two research assistants. Simple percentage was used to analyze the data collected for the research questions and Pearson product moment correlation was used to test the hypotheses at 0.05 levels of significance.

\section{RESULTS AND DISCUSSION}

In the bid to understand adult learners' motivation and readiness to learn, the demographical information of the respondents were retrieved and presented in Table 1.

Table 1 showed that $65 \%$ of respondents were female adult learners while $35 \%$ were male adult learners. On the age range of the respondents, $86 \%$ of the respondents indicated age range of 36-45 years old, $14 \%$ indicated age range of above 46 while none of the respondents indicated age range of 26-35 years old. For the working experience, $85 \%$ of the respondents indicated 16-25years of working experience, $10 \%$ indicated 615 years, $5 \%$ indicated below 6years while $2 \%$ indicated $26-$ 35years of workings experience. These data reflect that the respondents were adult learners.

It is necessary for adult learners to have m-learning devices before getting engaged in the m-learning educational experience. Table 2 presents the response of the respondents on the m-learning devices that they possess.

The consideration on the mobile devices that learners have is shown in Table 2, $100 \%$ of the respondents have a mobile device, $98.3 \%$ of the respondents acknowledge that their mobile devices have audio-visual properties, 99.2\% indicated that the mobile devices with them is connected to the internet service. $99.2 \%$ of the respondents also indicated that their mobile devices can store information for further access. In addition, $98.3 \%$ of the respondents indicated that their mobile devices are compatible with word document and PDF. However, these findings have shown that the respondents are in possession of the basic necessities for m-learning and can be involved in the m-learning stimulated learning experiences. There is need for adult learner to have the required skills for operating m-learning devices before engaging in m-learning experience.

There is need for adult learner to have the required skills for operating m-learning devices before engaging in $\mathrm{m}$ learning experience.

Table 3 showed the findings on the respondents' skills in operating mobile devices. It was revealed in Table 3 that $95.8 \%$ of the respondents are skillful in connecting mobile devices with the internet through WIFI, hotspot and modem. 98.3\% of the respondents can send and receive mails through their mobile devices. Furthermore, 97.5\% of the respondents agreed that they can download files from the internet using their mobile devices. It was also shown by $98.3 \%$ of the respondents that they can engage in learning through social media and learning management systems. It was indicated by all the respondents that they can surf the internet to get

Table 1. Demographic information of the respondents

\begin{tabular}{|c|c|c|c|c|c|c|c|c|}
\hline Gender & Frequency & $\%$ & Age Range & Frequency & $\%$ & Work Experience & Frequency & $\%$ \\
\hline Female & 78 & 65 & $26-35$ years & - & - & 6-15years & 12 & 10 \\
\hline \multirow[t]{2}{*}{ Male } & 42 & 35 & $36-45$ years & 103 & 86 & 16-25years & 102 & 85 \\
\hline & & & 46 years and above & 17 & 14 & 26-35years & 6 & 5 \\
\hline
\end{tabular}

Table 2. Respondents' m-learning devices

\begin{tabular}{|c|c|c|c|c|c|}
\hline No & Statement & Yes & $\%$ & No & $\%$ \\
\hline \multicolumn{6}{|c|}{ Respondents with m-learning devices } \\
\hline 1 & You have a mobile device (i.e., tablet, I-pad, I-phone, laptop, or PDA) & 120 & 100 & - & - \\
\hline 2 & Your mobile device has audio-visual properties & 118 & 98.3 & 2 & 1.7 \\
\hline 3 & Your mobile device is connected to the internet & 119 & 99.2 & 1 & 0.8 \\
\hline 4 & Your mobile device stores information & 119 & 99.2 & 1 & 0.8 \\
\hline 5 & You mobile device is compatible with word document and PDF on your mobile device & 118 & 98.3 & 2 & 1.7 \\
\hline
\end{tabular}

Table 3. Operational skills of mobile devices

\begin{tabular}{|c|c|c|c|c|c|}
\hline No & Statement & Yes & $\%$ & No & $\%$ \\
\hline \multicolumn{6}{|c|}{ What operational skills of mobile devices do adult learners have? } \\
\hline 1 & You know how to connect your mobile device with the internet through WIFI router, hotspot and modem & 115 & 95.8 & 5 & 4.2 \\
\hline 2 & You know how to send and receive e-mails through mobile device & 118 & 98.3 & 2 & 1.7 \\
\hline 3 & 1. You are skillful in downloading files from the internet through mobile device & 117 & 97.5 & 3 & 2.5 \\
\hline 4 & 2. You can engage in learning through Whatsapp, Zoom, Goggle class and Telegram & 118 & 98.3 & 2 & 1.7 \\
\hline 5 & 3. You can surf the internet for learning materials & 120 & 100 & - & - \\
\hline
\end{tabular}


Table 4. Use of mobile devices by adult learners

\begin{tabular}{|c|c|c|c|c|c|}
\hline No & Statement & Yes & $\%$ & No & $\%$ \\
\hline \multicolumn{6}{|c|}{ How often do adult learners use mobile devices? } \\
\hline 1 & You frequently use your mobile device & 120 & 100 & - & - \\
\hline 2 & You use mobile device on daily basis & 120 & 100 & - & - \\
\hline 3 & Mobile device is used for work at your work place & 120 & 100 & - & - \\
\hline 4 & You only use mobile devices for leisure & 2 & 1.7 & 118 & 98.3 \\
\hline 5 & You cannot do away with your mobile device & 119 & 99.2 & 1 & 0.8 \\
\hline
\end{tabular}

Table 5. Adaptability of adult learners to finance m-learning devices for learning

\begin{tabular}{|c|c|c|c|c|c|}
\hline No & Statement & Yes & $\%$ & No & $\%$ \\
\hline \multicolumn{6}{|c|}{ How will adult learners cope with the cost of using of m-learning devices for learning? } \\
\hline 1 & You are ready financially for m-learning & 120 & 100 & - & - \\
\hline 2 & M-learning may not be possible because of financial constraint & 2 & 1.7 & 118 & 98.3 \\
\hline 3 & Learning will be expensive through m-learning & 2 & 1.7 & 118 & 98.3 \\
\hline 4 & Your income will accommodate m-learning expense & 120 & 100 & - & - \\
\hline 5 & 6. Would you pay extra charges for m-learning & 116 & 96.6 & 4 & 3.4 \\
\hline
\end{tabular}

Table 6. Relationship between adult learners' motivation to learn and the use m-learning devices

\begin{tabular}{|c|c|c|c|c|c|}
\hline No & Statements & Yes & $\%$ & No & $\%$ \\
\hline \multicolumn{6}{|c|}{ What is adult learners' motivation to learn through m-learning? } \\
\hline 1 & It is interesting to learn through m-learning devices & 116 & 96.6 & 4 & 3.4 \\
\hline 2 & It is exciting to attend m-learning class & 118 & 98.3 & 2 & 1.7 \\
\hline 3 & It is motivating to use m-learning devices to perform learning task & 120 & 100 & - & \\
\hline 4 & You are continuously eager to participate in learning experiences that are facilitated by m-learning devices & 116 & 96.6 & 4 & 3.4 \\
\hline 5 & You are attracted to learn using m-learning devices & 116 & 96.6 & 4 & 3.4 \\
\hline
\end{tabular}

learning materials. Invariably, these respondents are skillful in operating mobile devices.

The frequent use of mobile devices by adult learners is indispensable in learning through m-learning class. Table 4 presents responses of the respondents on m-learning devices usage.

Table 4 considered data on the rate at which adult learners use mobile devices. It was presented that all the respondents indicated that they frequently use the mobile devices, they use mobile devices on daily basis and they also use mobile devices for professional purposes. $98.3 \%$ of the respondents expressed that they do not use mobile devices for leisure alone. $99.2 \%$ of the respondents were of the opinion that they cannot stop using mobile devices. These findings imply that the respondents frequently utilize the mobile devices.

The adaptability of adult learners to finance m-learning devices for learning is essential. Learning activities through mlearning requires that the learners will spend some money. Table 5 presents the response of the adult learners on their financial adaptability to m-learning educational channel.

Table 5 revealed that the entire adult learners are financially ready for the use of m-learning. $98.3 \%$ of the respondents opined that m-learning cannot be restricted due to financial constraint and they believe that learning cannot be expensive through m-learning. 100\% of the respondents indicated that their income will accommodate m-learning. 96.6 agree to pay extra charges for m-learning. Based on the findings above, it is noted that the respondents will be able to cope with the cost of learning through m-learning platform.

This study likewise explores the motivation of adult learners to learn through the use m-learning. Table 6 presents responses of the adult learners.
Table 6 showed that $96.6 \%$ of the adult learners are interested in learning through the use of m-learning devices. 98.3\% of the respondents likewise indicated that they are excited to attend m-learning class. Table 6 also revealed that the entire adult learners are motivated to use m-learning devices to perform learning task. $96.6 \%$ of the respondents indicated that they are constantly eager to participate in learning experiences that are facilitated by m-learning devices. $96.6 \%$ of the respondents also agree that they are attracted to learn using m-learning devices. Based on the findings above, it is noted that the respondents are motivated to learn through m-learning platform.

The participation of adult learners in an m-learning enhanced learning environment, students' readiness to learn through m-learning platform is crucial. Table 7 displays response of the respondents on their readiness to learn using m-learning.

Table 7 showed that $97.5 \%$ of the adult learners understand that learning can take place through m-learning devices. $98.3 \%$ of the respondents likewise indicated that they prefer to use m-learning for educational task. $97.5 \%$ of the respondents indicated that they are ready to learn using $\mathrm{m}$ learning devices. It was also revealed that the entire adult learners are positioned to use m-learning at school for learning effort. The table also presents that all the respondents indicated their preparedness to learn using m-learning devices. These findings imply that the respondents possessed the readiness to learn through $\mathrm{m}$-learning platform. 
Table 7. Readiness to learn via m-learning

\begin{tabular}{|c|c|c|c|c|c|}
\hline No & Statements & Yes & $\%$ & No & $\%$ \\
\hline \multicolumn{6}{|c|}{ What is adult learners' readiness to learn through m-learning? } \\
\hline 1 & You understand that learning can take place through m-learning devices & 117 & 97.5 & 3 & 2.5 \\
\hline 2 & You prefer to use m-learning for educational task & 118 & 98.3 & 2 & 1.7 \\
\hline 3 & You are ready to learn using m-learning devices & 117 & 97.5 & 3 & 2.5 \\
\hline 4 & You are positioned to use m-learning at school for learning effort & 120 & 100 & - & - \\
\hline 5 & You are prepared to learn through the use of m-learning devices & 120 & 100 & - & - \\
\hline
\end{tabular}

Table 8. Relationship between adult learners' motivation to learn and the use m-learning devices

\begin{tabular}{ccccccccc}
\hline Source of Variation & $\mathbf{N}$ & Mean & SD & df & Sig. & $\mathbf{r}_{\text {cal }}$ & $\mathbf{r}_{\text {tab }}$ & Result \\
\hline Use of m-learning & 120 & 9.95 & 0.3136 & & & Significant \\
\hline Students' motivation to learn & 120 & 9.93 & 0.3605 & 198 & 0.00 & 0.862 & 0.195 \\
$* \mathrm{p}<0.005$ & & & & & &
\end{tabular}

Table 9. Relationship between adult learners' readiness to learn and the use m-learning devices

\begin{tabular}{ccccccrrr}
\hline Source of Variation & N & Mean & SD & df & Sig. & ral $_{\text {cal }}$ & rtab $_{\text {Result }}$ \\
\hline Use of m-learning & 120 & 9.95 & 0.3136 & & & & Significant \\
\hline Students' readiness to learn & 120 & 9.88 & 0.5374 & 198 & 0.00 & 0.763 & 0.195
\end{tabular}
*p $<0.005$

The result in shown in the Table 8 revealed that $r_{\text {cal }}(0.862)$ is greater than $r_{\text {tab }}(0.195)$, i.e., $r_{\text {cal }}>r_{\text {tab. This }}$ implies that the null hypothesis is rejected at 0.05 significant level; hence, there is significant relationship between adult learners' motivation to learn and the use m-learning devices.

The result shown in the Table 9 revealed that $r_{\text {cal }}(0.763)$ is greater than $r_{\text {tab }}(0.195)$, i.e., $r_{\text {cal }}>r_{\text {tab. }}$ This implies that the null hypothesis is rejected, at 0.05 significant level; therefore, there is significant relationship between adult learners' readiness to learn and the use of $\mathrm{m}$-learning devices.

The first set of findings in this study revealed that the respondents have the basic mobile devices. The ownership of mobile devices is one of the basic necessities in the present world. It is somehow difficult to identify an environment whose human occupants do not have mobile devices. It has gotten to the stage that students at the primary and secondary schools have their personal mobile devices. Iqbal and Bhatti (2015) revealed that higher percentage of students own one mobile device or the other. This was also supported by Aina (2021) and Insorio (2021) through the initiative that the ownership of mobile devices is universal. It was also found out in this study that the respondents are skillful in the operation of mobile devices. This is in line with the outcome of a study conducted by Avwiri and Ewuruje (2021) which showed that undergraduates at University of Port Harcourt skillfully operate mobile devices.

In addition, it was also found out in this study that the respondents are skillful in operating mobile devices. it was also revealed in this study that adult learners at the universities in Southwest, Nigeria frequently utilize the mobile devices which are the channel through which m-learning disseminates learning contents. This can be backed with Al-Rahmi et al.'s (2021) insight that higher education students utilized mobile devices for educational effort. The ability of the adult learners to use mobile devices points that the respondents will be able to fit in properly into the m-learning environment. The consistent use of mobile devices is based on its flexibility, portability and durability. It is convenient for learners to make use of mobile devices at any location and anytime without any discomfort. This explains why m-learning provides teaching and learning experiences to learners regardless of location and time.

Furthermore, the findings of this work likewise showed that the adult learners will be able to cope with the cost of learning through m-learning. In view of the fact that the cost of mobile devices for pleasurable activities does not differ from using it for learning activities shows that adult learners that can financially maintain the use of mobile devices for social activities can equally cope financially in an m-learning environment. The use of mobile devices is cost effective at all levels of education due to easy download of texts and other learning materials (Karuna et al., 2021). It was obvious that mlearning requires finance, it does not require huge sum of money that adult learners cannot afford. One the outcomes of this study revealed that the respondents are motivated to learn through m-learning platform. Hence, m-learning is a motivating platform for learners at different educational milieu (Aremu, 2021). It was also found out in this study that the adult learners possessed the readiness to learn through mlearning platform. Karuna et al. (2021) confirmed this result through a view that learners portray some forms of learning readiness when exposed to mobile devices in an academic setting. Finally, it was also identified in the study that there is significant relationship between adult learners' motivation to learn and the use of m-learning devices, as well as significant relationship between adult learners' readiness to learn and the use of m-learning devices. These might be based on the fun and captivating nature of m-learning devices in enhancing students' motivation to learn (Oyelere et al., 2016; Parmigiani et al., 2015; Rahamat et al. 2017; Sung et al., 2016; Wongkhamdi, et al., 2017).

\section{CONCLUSION}

The use of m-learning devices is one of the ways through which learners can have uninterrupted learning experience, as 
it was developed to proffer solution to the barrier of location, distance and time. In view of the findings of this study, this work concludes that adult education students have the basic mobile devices, skills to operate the devices and frequently use the devices; more so, finance is not a limitation for the use of m-learning by adult education students. Learners at adult education programmes can be fully involved in the m-learning stimulated learning experiences as the use of m-learning devices is correlated with the motivation and readiness of adult learners to learn.

\section{RECOMMENDATIONS}

Based on the outcomes of this study, it was recommended that the utilization of m-learning for teaching and learning experience should be formally introduced into adult education programme in Nigeria. This will help the adults to learn while working; it will also help to overcome the challenges of clashes between lectures and work. The introduction of m-learning into adult education programme will likewise provide adult learners with opportunity to connect with wider materials for their studies through online sources. This will motivate adult learners to undertake learning activities voluntarily as well as readiness to learn. It was also recommended that awareness should be given to adult learners, adult education teachers and schools on the benefits of m-learning facilitated teaching and learning experience. Knowledge of the value of m-learning to students, teachers and the school will motivate and foster readiness in an academic environment. It was further recommended that ministry of education and other stakeholders in education should partner with mobile devices manufacturers to make m-learning devices available for teaching and learning activities.

Author contributions: All co-authors have involved in all stages of this study while preparing the final version. They all agree with the results and conclusions.

Funding: No external funding is received for this article.

Acknowledgements: The research assistants and the adult learners of the three Federal Universities at Southwest, Nigeria used for this study are well appreciated.

Declaration of interest: The authors declare that they have no competing interests.

Ethics approval and consent to participate: Not applicable. Availability of data and materials: All data generated or analyzed during this study are available for sharing when appropriate request is directed to corresponding author.

\section{REFERENCES}

Adeji, E., \& Tunde, M. (2020). Problems and prospects of adult education in Nigeria. INOSR Humanities and Social Sciences, 6(1), 7-13. http://www.inosr.net/inosr-humanities-andsocial-sciences

Aina, J. K. (2021). Mobile learning for colleges of education pre-service teachers during COVID-19 pandemic. Journal of Scientific and Engineering Research, 8(2), 1-9.
Al-Rahmi, A. M., Al-Rahmi, W. M., Alturki, U., Aldraiweesh, A., Almutairy, S., \& Al-Adwan, A. S. (2021). Exploring the factors affecting mobile learning for sustainability in higher education. Sustainability, 13, 1-22 https://doi.org/10.3390/su13147893

Aremu, B. V. (2021). The use of mobile learning to improve students' motivation and achievement of learning outcomes. Kampala Journal of Humanities, 6(2), 175-183.

Avwiri, E., \& Ewuruje, U. G. (2021). Awareness and use of mobile devices for the teaching and learning of physics, amongst undergraduate students at the University of Port Harcourt, Nigeria. International Journal of Innovative Social and Science Education Research, 9(1), 85-90.

Barreh, K. A., \& Abas, Z. W. (2015). A framework for mobile learning for enhancing learning in higher education. Malaysian Online Journal of Educational Technology, 3(3), 19.

Cheon, J., Lee, S., Crooks, S. M., \& Song, J. (2012). An investigation of mobile learning readiness in higher education based on the theory of planned behavior Computers \& Education, 59, 1054-1064. https://doi.org/10.1016/j.compedu.2012.04.015

Federal Government of Nigeria. (2004). The national policy on education. National Educational and Research Development Council.

Harandi, S. R. (2015). Effects of e-learning on students' motivation. Procedia - Social and Behavioral Sciences, 181, 423-430. https://doi.org/10.1016/j.sbspro.2015.04.905

Insorio, A. O. (2021). Technological and operational mobile learning readiness of secondary teachers. International Journal of Pedagogical Development and Lifelong, 2(1), 1-10. https://doi.org/10.30935/ijpdll/9362

Iqbal, S., \& Bhatti, Z. A. (2015). An investigation of university student readiness towards m-learning using technology acceptance model. International Review of Research in Open and Distributed Learning, 16(4), 83-102. https://doi.org/10.19173/irrodl.v16i4.2351

Karuna, S. F., Srinkant, M. K., and Vanlin, S. (2021). The review of mobile applications and wireless technologies in sustaining K-12 schools during COVID-19. Transactions on Mobile Communications and Applications, 6(8), 1-14.

Kukulska-Hulme, A., \& Sharples, M. (2016). Waypoints along learning journeys in a mobile world. In W. $\mathrm{Ng} \& \mathrm{~T}$. M. Cumming (eds.), Sustaining mobile learning: Theory, research and practice (pp. 43-56). Routledge. https://doi.org/10.4324/9781315766553-3

Kukulska-Hulme, A., Gaved, M., Jones, A., Norris, L., \& Peasgood, A. (2017). Mobile language learning experiences for migrants beyond the classroom. In J.-C. Beacco, H.-J. Krumm, D. Little, \& P. Thalgott (Eds.), The linguistic integration of adult migrants: Some lessons from research (pp. 219-224). De Gruyter. https://doi.org/10.1515/ 9783110477498-030

Levy, Y., Ramimand, M. M., \& Hackney, A. R. (2013). Assessing ethical severity of e-learning systems security attacks. Journal of Computer Information Systems, 53(3), 75-84. https://doi.org/10.1080/08874417.2013.11645634 
Miller, H. B., \& Cuevas, J. A. (2017). Mobile learning and its effects on academic achievement and student motivation, International Journal for the Scholarship of Technology Enhanced Learning, 1(2), 91-110.

Oyelere, S. S., Suhonen, J., \& Sutinen, E. (2016). M-learning: A new paradigm of learning ICT in Nigeria. International Interactive Mobile Technologies, 10(1), 35-44. https://doi.org/10.3991/ijim.v10i1.4872

Padmanathan, Y., \& Jogulu, L. N. (2018). Mobile learning readiness among malaysian polytechnic students. Journal of Information System and Technology Management, 3(8), 113-125.

Parmigiani, D., Traverso, A., \& Pennazio, V. (2015). Mobile devices as factor for the development of motivation and concentration in the upper secondary school. The students' and parents' point of view. Conference Paper (pp. 172-179).

Rahamat, R. B., Shah, P. M., Din, R. B., \& Aziz, J. B. A. (2017). Students' readiness and perceptions towards using mobile technologies for learning the English language literature component. The English Teacher, 40, 69-84.
Saxena, A., \& Saxena, A. (2015). A viewpoint and attitudes of students' towards future of mobile learning in education industry of India. International Journal of Management, MIT College of Management, 3(1), 18-22.

Sudarsana, I. K., Armaeni, K. W. A., Sudrajat, D., Abdullah, D., Satria, E., Saddhono, K., \& Ekalestari, S. (2019, November). The implementation of the e-learning concept in education. Journal of Physics: Conference Series, 1363(1), 1263.

Sung, Y. T., Chang, K. E., \& Liu, T. C. (2016). The effects of integrating mobile devices with teaching and learning on students' learning performance: A meta-analysis and research synthesis. Computers \& Education, 94, 252-275. https://doi.org/10.1016/j.compedu.2015.11.008

Wongkhamdi, T., Cooharojananone, N., \& Khlaisang, J. (2017). The study of mobile learning readiness in rural area: Case of North-Eastern of Thailand [Paper presentation]. International Symposium on Computers in Education. IEEE. https://doi.org/10.1109/SIIE.2017.8259665 